\title{
Trashing the millenium: Subjectivity and technology in cyberpunk science fiction
}

\begin{abstract}
'Cyberpunk' science fiction is a self-proclaimed movement within the genre which began in the J980s. 45 the name suggests, it is an cxtrapolative form of science fiction which combines an almost obsessiona' interest in machines (panicularly information machines) with an anarchic, anoral, streetwise sensibilin This paper sketches the development of the movemen and seeks to make qualificd claims for the radica. potenial of its fiction. Of cricial imporance are the wovs in which human subjectivin (viewed ": psychoanalytic tenns) interacts with 'technological subjectivity' in cybemunk. particularh with regard " the implications of these interactions for oedipalization.
\end{abstract}

\section{The future}

It is the end of the century. An appropriate time to talk about the future. The entropic vision of the great J.G. Ballard sees it thus:

.. the future may not exist as a concept, just as the past virtually doesn't exast anymore. The past is just a kind of anthologv of design statements that one dips into ... . It doesn't have any real validity ... I think the biggest thing (about the futurc| is that human beings will have. for the first time, the ... right to trcat their own psychopathologics as a game ... . (Ballard, 1991:71)

In the same issue of the British magazine Blitz, Jonathan Romney (1991:103) writes:

Futures imagined today are the ones which are immediately possible, virtually present. Accelerating technological advance has effectively wiped out the idea of "undiscovered country" - the scientific territory to be explored now has not to be discovered, but mapped in, in ever finer detail, decoded ever more subtly. This impulse inwards is neatly represented by the infinilive visual tracking-in of fractals in chaos theory ... .

Commonly in popular culture, it is science fiction (hereafter SF) which has envisioned the future. Not all SF, of course, is entropic in the ways Ballard and Romney describe. If we accept, however, the increasingly widely-held view that our dominant culture, the culture of Western multinational corporate capitalism, is technological and postmodernist, then SF which extrapolates its narratives from available technological information and which portrays the 'subjects' of those narratives as decentred and frequently pathological, may be the late twentieth-century's nearest equivalent to the bourgeois realist novel. 
This argument makes the broad assumptions that the 'culture' I refer to is indeed technological, which few would dispute, and postmodernist, which perhaps more than a few would dispute. My intention in this paper is to contend that certain recent SF represents a potentially radical move in fiction, one which I believe to be postmodernist and to have crucial implications beyond the frame of the text, implications concerning what we perceive 'the future' to be. This is the SF described as 'cyberpunk'.

\title{
2. What is cyberpunk?
}

Cyberpunk SF is a self-proclaimed (and anthologized) movement within the genre which began in the early 1980 s and continues to the 'present'. Its manifesto is the 1988 collection of short stories, Mirrorshades: The Cyberpunk Ant/ology, edited and introduced by one of the most influential cyberpunk writers, Bruce Sterling. In his introduction he explains the label:

... much as punk stripped rock and roll of the symphonic elegances of Seventies "progressive rock" ... cyberpunk is in some sense a return to roots. The cyberpunks are perhaps the first SF generation to grow up not only within the literary tradition of science fiction but in a truly science-fictional world. (Sterling, 1988:vii-ix.)

Sterling points to the pervasiveness of technology in our world, 'a truly science-fictional world'. His introduction in Mirrorshades situates the cyberpunks firmly within the 'literary tradition' of SF, even diligently naming their influences and precursors, but he is concerned above all to delineate the difference of the movement. In doing so he points to those preoccupations in cyberpunk which precisely concern my own argument:

\begin{abstract}
For the cyberpunks ... technology is visceral... . Technology itself has changed. Not for us the giant steam-snorting wonders of the past ... . Eighties tech sticks to the skin, responds to the touch ... . Certain central themes spring up repeatedly in cyberpunk. The theme of body invasion: prosthetic limbs, implanted circuitry, cosmetic surgery, genetic alteration. The even morc powerful theme of mind invasion: brain-computer interfaces, artificial intelligences, neurochemistry - techniques radically redefining ... the nature of the self. (Sterling. 1988:xi.)
\end{abstract}

\subsection{Some cyberpunks}

Here are some states-of-the-art: Rudy Rucker's novel Wetware, published in 1988, is about a race of cybernetic organisms, originally built by humans, who live on the moon. They discover how to build a new superhuman Lifeform, called 'Manchile', by infusing organic DNA with their own software code. Consequently, the reader can delight in chapter headings such as "People That Melt" and chapter four of the book, "In which Manchile, the First Robot-Built Human, Is planted in the Womb of Della Taze by Ken Doll, Part of Whose Right Brain is a Robot Rat".

In Bruce Sterling's Schismatrix (1985), the hero, Abelard Lindsey, complete with prosthetic right arm, wanders the Solar System like the Flying Dutchman, using his genetic implantation to manipulate whole societies. The Earth has been 'trashed and melted' and existence is now comprised of the stellar republics of the solar system - the 'schismatrix'.

K.W. Jeter's work utilizes the cut-up narrative technique developed by William Burroughs, a cyberpunk hero, especially in the novel The Glass Hammer (1985). In this novel, the cyberpunk anti-hero Schuyler, is a drunken 'sprinter' - a racing car driver who is literally 
wired into his computerized vehicle - who transports illegal drugs across the deserts of America. He is pursued by computerized weapons systems, and the nightly desert run is filmed as prime-time television. Much of the narrative describes the storyboard of the video shots, in a rapidly oscillating fast-cut prose.

The last author in this brief survey is the best-known, the most acclaimed and is credited with starting the cyberpunk movement. William Gibson's debut novel, Neuromancer (1984), is rated by Bruce Sterling as "surely the quintessential cyberpunk novel" (1988:xii). and has become a sort of 'limit-text' of the movement. Before sketching some salıent points about that novel, I wish to turn to an earlier short story by Gibson, anthologized in Mirrorshades, which I believe prefigures the central textual strategy of later cyberpunk. The story is entitled "The Gernsback Continuum". It concerns a freelance photographer who is assigned to photograph futuristic Thirties and Forties American architecture for an illustrated history entitled "The Airstream Futuropolis: The Tomorrow that never Was". His boss tells him to "think of it as a kind of alternate America: a 1980s that never happened. An architecture of broken dreams". Researching the project, he is struck by the plan for a 1936 airliner, "like a fat symmetrical boomerang with windows in unlikely places. Labelled arrows indicated the locations of the grand ballroom and two squash courts" (Gibson, 1988:3). The plane, of course, had never been built, but after davs oi photographing California gas stations designed by Ming the Merciless, with lots of "ravgun emplacements in white stucco", the photographer

... penetrated a fine membrane, a membrane of probability... Ever so gently. 1 went over the Edge And looked up to see a twelve-engined thing like a bloated boomerang. all wing. thrumming its was east with an clephantine grace, so low that I could count the rivets in its dull silver skin, and hear maybe - the echo of jazz. (Gibson. 1988:5.)

The photographer has entered the Gernsback continuum of the title, a future envisioned by the Science Fiction pulp magazines of the Thirties edited by Hugo Gernsback, a technophilic future which never came to be - or did it? I want to leave our downbeat lensman in his parallel universe for the moment, and turn to Gibson's debut novel Neuromancer. over which much panegyric has wafted. The following selections from contemporary reviews should serve to situate and describe the novel, and should give some idea of its critical impact:

... Neuromancer is a science fiction crime thriller of corporate intrigue, describing urban life in a future dominated by multinational corporations and computer technology. (Hall, 1986:139.)

Case (the protagonist of Neuromancer) is a computer jock, a "console cowboy" who leaves his body behind when he plugs in and soars through the inner world of cyberspace... . His criminal underworld of the near future has supplemented the staples of drugs and sex with illegal neurosurgery and stolen data... . It is a world furnished from a melange of memories; the computer folklore of Tron and War Games; the rundown high-tech look of Blade Runner and the moral ambience of 40's film noir. (Anonymous revicw quoled in Hall, 1986:139.)

In Neuromancer William Gibson imagines a future pervaded by micro-processes, electronic and surgical, in which information is the prime commodity. Cowboys like ... Case make their living rustling data for unscrupulous [corporate] employers... . They plug their own brains directly into their computers, to penetrate a shared dream-world [called cyberspace] where information exchange appear|s] as tangible, luminous blocks, like geometric skyscrapers. (Greenland, 1984:1420.)

In the novel, Case is employed, with the help of a genetically and surgically altered female ninja assassin called Molly, and his old mentor McCoy Pauley, who died while his mind was in cyberspace on a job and who was genetically encoded on a ROM hardware construct. to 
free an Artificial Intelligence named Wintermute from its bondage to a multinational corporation. Wintermute is then able to reunite with its severed libidinal half, the Neuromancer of the title, to become a sort of god of cyberspace at the end of the book, which is in a sense a little disappointing.

\section{The body and the cyborg}

Thus the cyberpunk scene is set. What is at stake in all these 'futures'? Jonathan Romney (1991:103) opines that

... the body is at stake in all these futures ... . The body is traditionally the ultimate referent in social and political discourse. If we now feel inadequate to imagine any future other than variants on the present, it's because the body, and the laws ... read into it, seem to be going over the brink into a weird, unreadable zone.

Cyberpunk SF, like the photographer in the Gernsback continuum, is representing the penetration of a 'membrane of probability' which is the surface of the body, the matter of consciousness, and even unconsciousness. By setting the future within the self-referential and self-consuming frame of the body, it is making that weird zone readable, consumable perhaps in new ways, ways appropriate to postmodernist, technologized epistemologies.

The brief resumés of Cyberpunk novels I have deliberately selected, point to the decentering of the realist or mimetic human subject, decentred through the subjectivity of the postmodernist machine/man, Donna Haraway (1990:192) calls the cyborg:

... the cyborg is ... the awful apocalyptic telos of the West's escalating dominations of abstract individuation, an ultimate self untied at last from all dependency, a man in space. An origin story in the Western humanist sense depends on the myth of original unity, fullness, bliss and terror, represented by the phallic mother from whom all humans must separate, the task of individual development and of history, the twin potent myths inscribed most powerfully for us in psychoanalysis and Marxism.

Cyberpunk is the fiction of the cyborg. It may be the beginning of a post-humanist, postoedipal popular fiction, since it need not be determined by "the myth of original unity", the imaginary Imaginary. The oedipal subject is tied irrevocably, ideologically to that myth, but not so the cyborg. Rucker's Wetware exactly problematizes oedipalization, makes it, in a sense, the subject of the novel, since the 'Boppers', the robots who manufacture the Manchile cyborg, need to implant the fetus in a 'meatie'. Case, too, embodies (or is that disembodies?) the "apocalyptic telos of ... abstract individuation" by his interface with cyberspace, his body 'flatlining' for longer and longer periods as his consciousness explores deeper and deeper into the vector-gridded cyberspace 'Matrix'.

Yet that 'Matrix' is not the oedipal Mother either, for this womb is studded with ICE Intrusion Countermeasures Electronics - waiting to deal with the trespassing of meatpuppets like Case - Case, encased in his prison-house of flesh, can feel no imaginary unity with this cybernetic chora. Gibson's Matrix of cyberspace information DNA becomes Sterling's Schismatrix, stellar societies oscillating wildly with, again, no "myth of ... unity". 


\section{Reality and the 'desiring-machine'}

If cyberpunk is, indeed, post-oedipal (and this is in no way a comprehensive assertion). then its technologized subjects find a place in the world of Deleuze and Guattari's AntiOedipus. In their pointedly ludic fomulation: "The real is not impossible; it is simply more and more artificial" (Deleuze \& Guattari, 1984:34). Here, of course, they refer to the Lacanian real, but the 'reality' of representation is that there is no 'reality' in representation, only 'simulacra', 'copies without originals', cyborgs with no phallic mothers. The anti-oedipal 'desiring-machine' is a machine which continually breaks down, which exists to break the flow of production, to escape the psychoanalytic logic of lack-desire. production-consumption. The desiring-machine's 'function' is to break down, to stop this flow, a flow which maintains the Western myth of origin, which itself maintains production. Deleuze and Guattari trope the desiring-machine as the "body without organs":

The body without organs is an egg: it is crisscrossed with axes and thresholds, with latitudes and longitudes and geodesic lines, traversed by gradients marking the transitions and the becomings, the destination of the subject developing along these particular vectors. (Deleuze \& Guattari, 1984:19.)

The subjects of cyberpunk at times defeat the oedipal logic of otherness in their dissolution into the machine. Gibson's crucial trope of cyberspace is eerily close to Deleuze and Guattari's conception here. Cyberspace could well be the body without organs, information DNA matrix, pure self-producing, self-consuming commodity data. A relation of otherness makes no sense here, because the rules of production/consumption no longer apply. Case, the subject, develops along the vectors of a machine which demands no desire because as other it has become its own subject, its own desire. Case must do the same.

\section{The end of signification}

This "particular vector", however, the complete dissolution of the subject, presents a problem even for the anarchic sensibilities of the technopunks. The problem is, of course. the end of signification. So far, cyberpunk has not faced it, generally preferring the solutions sought by the zoned-out photographer of Gibson's short story, who I mercifully haven't forgotten. He takes a photograph of the flying silver boomerang and shows it to his friend Mervyn Kihn, roving investigator of serious UFO weirdnesses. Merv is less than encouraging: "Its good," he says, "but it's not mental!" He explains:

... I'd say you saw a scmiotic ghost. All these contactee stories, for instance, are framed in a kind of sci-fi imagery that permeates our culture. I could buy aliens, but not aliens that look like Fiftics comic art. They're semiotic phantoms, bits of deep cultural imagery that have split off and taken on a life of their own ... . (Gibson, 1988:7.)

The photographer later sees another "semiotic ghost": the "illuminated city" of the pulp SF magazines, all gleaming ziggurats and spires, and in front of it the embodiment of that continuum's American Dream. A blond, blue-eyed all American couple, dressed in loosefitting radiant white. She turns to him and says "John, we've forgotten to take our food pills".

Panicking, our photographer phones Merv. Merv's advice?

Watch lots of television, particulary game shows and soaps. Go to porn movies ... . I'm letting you in on a trade secret: Really bad media can cxorcise your semiotic ghosts. If it keeps the saucer people 
off my back, it can keep those Art Deco futuroids off yours. Try it. What have you gol to lose?

(Gibson, 1988:10.)

This brilliant story is not so much SF as about SF. Sterling's assertion that the cyberpunk writers are the first to have grown up in 'a truly science-fictional world' is here convincingly illustrated. Cyberpunk's postmodernism may be described as self-consuming rather than self-reflexive, because, perhaps more than other fictional genres, SF partakes of other popular cultural forms - it does not merely refer to these, but consumes them as discourse. At the narrative level, this is represented by figures like Case and Molly in Neuromancer. In an interview, Gibson (1985:17) describes Molly as "an elaborate paste-up from Clint Eastwood movies, Bruce Lee, Emma Peel, Chrissie Hynde's cheekbones on the cover of the first Pretenders album ..."

Many of the cyberpunk novelists utilize SF's affinity with other pulp-fiction genres like the Western and the hard-boiled detective genre, whose 'semiotic ghosts', of course, are all roaming in the culture machine. This points to what I have described as the central textual strategy of cyberpunk, which, apart from its self-consuming simulacra, presents the reader with what might be termed an entropic feedback loop. I would like to recall Ballard's (1991:71) comment that the "past is ... a kind of anthology of design statements ... [with no] real validity". The "Gernsback Continuum" illustrates the semiotic or textual nature of that past - that the past is not real, but (science) fictional, simulated. But this would imply that the future, as Ballard also says, "may not exist as a concept". SF becomes the record of the present, not the vision of the future. If cyberpunk's technohackers and street hustlers have defeated oedipus through their jacking into the machine, they will need to reinvent the past rather than invent the future.

\section{Back to the future}

It comes as no surprise, therefore, that Gibson and Sterling's latest collaborative work (1990) is an alternative history novel set in a fin de siecle 19th-century London. Entitled The Difference Engine, its London has the cluttered baroque quality of the typical cyberpunk city, where, in Gibson's famous axiom, "the street finds its own uses for things".

As far as its millenial vision is concerned, it seems that the cyberpunks are utilizing a new kind of popular history, a textualized history, full of its own 'semiotic ghosts'.

In Romney's words, "it's as if culture now were checking itself against culture then, to see how its own sense of apocalypse shapes up" (1991:103). However, the cyberpunk writers seem to know that to defeat history is impossible, that even the most radically apocalyptic SF novel is still an object in culture - so, perhaps apocalypse is the postmodern pathology we treat as a game.

If we were able to envision ourselves truly in the last days of culture, then the fictional objects of culture, in this case the narratives of SF, would be in the position of the ultimate paradox - narratives about the end of narratives. Since this is patently not the case, perhaps the universe has a few years left! 


\section{References}

Ballard, J.G. 1991. Interview. Blitz, 100:71. May.

Deleuze, G. \& Guattari, F. Anti-Oedipus. London : Athlone Press.

Gibson, W. 1984. Neuromancer. London: Grafton.

Gibson, W. 1985. Interview in Interzone, 13:17-18. Autumn.

Gibson, W. 1988. The Gernsback Continuum. In: Sterling, B. (ed.) Mirrorshades: The Cyberpunk Anthology. London: Paladin.

Greenland, C. 1984. 'Possess, Integrate, Inform'. In: Hall, S. 1986. Confemporary Literary Criticism Yeanook. Detroit : Gale.

Hall, S. (ed.) 1986. Contemporary Literary Criticism Yearbook. Detroit : Gale.

Haraway, D. 1990. A Manifesto for Cyborgs. In: Nicholson, Linda. J. (ed.) Feminism/Postmodemism. London : Routledge. p. 190-233.

Jeter, K.W. 1985. The Glass Hammer. London : Grafton.

Romney, J. 1991. Endgame. Blitz : 100, May.

Rucker, R. 1988. Wetware. London : New English Library.

Sterling, B. 1985. Schismatrix. Harmondsworth : Penguin.

Sterling, B. (ed.) 1989. Mirrorshades: The Cyberpunk Anthology. London : Paladin.

Sterling, B. \& Gibson, W. 1990. The Difference Engine. London : Gollancz.

\section{Vista University (East Rand Campus - Benoni)}


